\title{
Spanish research to receive funding boost
}

[BARCELONA] Spain plans to raise spending on research and development (R\&D) from its current level of $0.8-0.9$ per cent of gross national product (GNP) to 1.2 per cent over the next four years.

This could mean a 10 per cent increase in the government's science budget next year, say officials. The increased funding is promised in a national plan on $\mathrm{R} \& \mathrm{D}$, outlined to the Senate recently by the minister of education and culture, Mariano Rajoy.

The plan is due to be approved by the cabinet in October. Government officials say the increased effort will be achieved through "slow and sustained increases" in public investment in research, and will be "reviewed annually".

Rajoy told the Senate that the government is keen to encourage more private investment in research, to strengthen the international nature of Spanish science, and to enhance the scientific and technological culture of society.

He said that special emphasis will be put on recruitment and employment issues, including long-term contracts for experienced researchers at research institutes, and support for postdocs to become involved in entrepreneurial activities.

Spain's current level of R\&D spending is well below the average of 2.2 per cent of GNP for countries belonging to the Organization for Economic Co-operation and Development. And public spending is still higher than that in the private sector.

The national plan will take account of proposals from Spain's regions, and covers basic and applied research. It has been divided for funding and administrative purposes into one basic research area with no immediate practical applications, and nine scientific and technological areas, including biomedicine, biotechnology, information and communication technologies. There are also 12 sectors considered of special interest to the government, such as defence, energy, space and aeronautics.

Fernando Aldana, director of the Office for Science and Technology, admits that initially more than half of public R\&D spending will remain devoted to defence. But he says that the level "will decrease progressively" in favour of civil research. He would like to see total R\&D spending in Spain reach 1.5 per cent of GNP in the next decade, with 60 per cent of the investment coming from the private sector.

Although the way the extra money is to be spent is still being discussed, Aldana says that basic research disciplines to be given priority will include astrophysics, particle physics and thermonuclear physics.

He says these relate to areas in which Spain has already made significant contributions to major international projects, including the

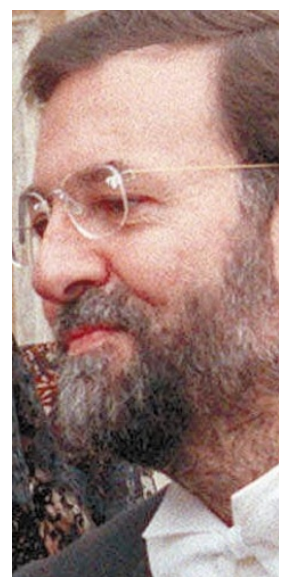

Gran Telescopio de Canarias, the European Laboratory for Particle Physics, and the Stellerator TJ-II nuclear fusion reactor at the Spanish Centre for Energy, Environment and Technology Research.

Aldana says that private investment will be essential if the government's targets are to be met. Tax relief for corporate $\mathrm{R} \& \mathrm{D}$ programmes Rajoy: wants more private investment.

will therefore be included in the strategy. He points out that Spain imports 157 billion pesetas (US\$1 billion) worth of technology annually, but exports only Pts 24 billion worth.

Francisco José Rubia-Vila, director of research of the Community of Madrid, welcomes the planned increase in public spend- ing. He says it should allow the "integration of postdocs trained abroad as well as a renewal of infrastructure" and is also confident that private investment will be stimulated.

Francisco Medina-Mena, an electronics researcher at the University of Seville, agrees with the attempt to involve industrial sectors in defining research objectives.

Aldana says one of the novelties of the plan is the "identification of strategic actions involving different sectors". Priorities will be identified for each industrial sector, and scientists will be able to draw on these when putting forward requests for funding.

But others warn that increased funding alone will not improve the functioning of the system. Jesús Martínez-Frías, a geologist at the National Museum of Natural Sciences in Madrid, says there is a need to break down barriers between institutions with responsibility for science. "The functions of each must be defined with clarity and transparency."

$\mathrm{He}$ also says that there should be closer coordination with international scientific bodies to avoid excessively 'domestic' policies.

\section{Monkey dispute halts Indian drug tests}

[NEW DELHI] A number of drug research projects in India have been halted because of a conflict between a government animalwelfare committee and a Hyderabad centre that supplies animals to research institutes.

Under rules introduced in December 1998, all laboratories that breed or experiment with animals must register with the Committee for the Purpose of Control and Supervision of Experiments on Animals. The committee is chaired by Maneka Gandhi, the minister for social justice and herself an animal activist.

Although the National Centre for Laboratory Animal Science (NCLAS) has twice applied for registration, this has been refused on the grounds that the centre uses monkeys caught in the wild rather than laboratory bred, and that these are kept in cages that fall below international standards.

The committee's secretary, A. P. Singh, last week ordered NCLAS to release all monkeys back to the wild as a condition of registration. But the centre has refused on the grounds that the monkeys were caught with permission from the forest department, and are being used for research under contract with drug companies.

Without registration, NCLAS chief scientist $\mathrm{S}$. Hariharan says, normal activities at the centre cannot continue. "We have stopped breeding laboratory animals and supplying them to our clients, and have also halted on-going projects," he says.

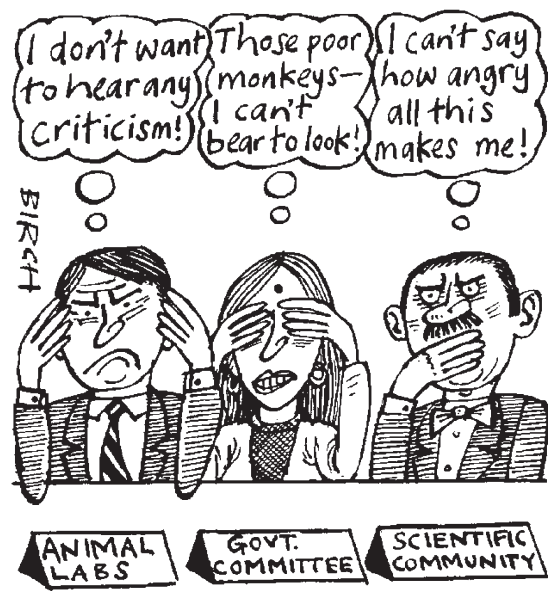

NCLAS is recognized as a centre of excellence by the International Council of Laboratory Animal Sciences and the World Health Organization, and trains scientists from several countries besides India. The centre has more than 30,000 animals, including strains of mice and rats that have been bred over several decades. "If they are lost, it will take another 20 years to establish similar colonies," says Hariharan.

Singh says his committee does not want to harm biomedical research, but he adds: "We have to implement the rules. And I cannot shut my eyes to how the monkeys are kept in NCLAS." But NCLAS scientists say the committee's conditions amount to closing down the facility. 